University of Nebraska - Lincoln

DigitalCommons@University of Nebraska - Lincoln

Faculty Papers and Publications in Animal

Science

Animal Science Department

1967

\title{
Availability of Niacin in Corn and Milo for Swine
}

W. G. Luce

Nebraska Agricultural Experiment Station

E. R. Peo, Jr.

University of Nebraska-Lincoln

D. B. Hudman

Nebraska Agricultural Experiment Station

Follow this and additional works at: https://digitalcommons.unl.edu/animalscifacpub

Part of the Animal Sciences Commons

Luce, W. G.; Peo, Jr., E. R.; and Hudman, D. B., "Availability of Niacin in Corn and Milo for Swine" (1967).

Faculty Papers and Publications in Animal Science. 627.

https://digitalcommons.unl.edu/animalscifacpub/627

This Article is brought to you for free and open access by the Animal Science Department at DigitalCommons@University of Nebraska - Lincoln. It has been accepted for inclusion in Faculty Papers and Publications in Animal Science by an authorized administrator of DigitalCommons@University of Nebraska - Lincoln. 


\title{
AVAILABILITY OF NIACIN IN CORN AND MILO FOR SWINE ${ }^{1}$
}

\author{
W. G. Luce, E. R. Peo, JR. and D. B. Hudman ${ }^{2}$ \\ Nebraska Agricultural Experiment Station, Lincoln
}

$\mathrm{N}^{1}$ IACIN has been recognized for several years as a dietary essential for swine. Its presence in feedstuffs is well known, but the biological availability of niacin in certain cereal grains commonly fed to swine has not been clearly established. Research has been reported indicating the niacin of white corn and wheat is largely unavailable to the pig (Kodicek et al., 1956; Kodicek et al., 1959 and Luce et al., 1966). Several workers have also obtained evidence that the niacin of corn is in a bound form and largely unavailable to the rat. (Laguna and Carpenter, 1951; Pearson et al., 1957; Harper et al., 1958; Kodicek and Wilson, 1959; Squibb et al., 1959 and Kodicek, 1960).

$\mathrm{No}$ information could be found in the literature on the availablity of niacin in yellow corn and milo for swine, therefore these studies were conducted.

\section{Experimental Procedure}

Experiment 1. Twenty-four cross bred barrows which averaged $20.3 \mathrm{~kg}$. of body weight were allotted at random to six replications of four treatments. The experiment was conducted for 70 days. The pigs were housed and individually fed in concrete-floored pens which were equipped with self-feeders and waterers. The experimental unit was completely enclosed and was equipped with a thermostatically-controlled heating system. Temperature in this unit was maintained at approximately $20^{\circ} \mathrm{C}$.

Composition of the experimental rations is presented in table 1 . The purified ration which assayed $1.85 \mathrm{mg}$. niacin per $\mathrm{kg}$. was fed with and without a supplement of 17.6 $\mathrm{mg}$. of niacin per $\mathrm{kg}$. of feed. The corn ration which contained $13.5 \mathrm{mg}$. of total niacin per $\mathrm{kg}$. of feed was also fed with and without a supplement of $17.6 \mathrm{mg}$. of crystalline niacin

\footnotetext{
1 Published with the approval of the Director as paper No. 1772, Journal Series, Nebraska Agricultural Experiment Station.

${ }^{2}$ Department of Animal Science. Acknowledgement is made to John Welch for assistance in development of certain of the laboratory procedures and to $\mathrm{P}$. F. Cunningham and associates for care of the experimental animals.
}

per kg. of feed. Vitamin-free casein and gelatin were used as protein supplements to maintain the total protein content of all rations at approximately $16 \%$. The calculated tryptophan content was held constant $(0.14 \%)$ in all treatments.

The growth study was terminated on the 58 th day of the experiment and a metabolism trial was conducted on the surviving 19 pigs. Total collections of feces and urine were made for 3 days after a 3-day adjustment period.

Experiment 2. Sixteen Yorkshire-Hampshire crossbred barrows which averaged 37.0 $\mathrm{kg}$. of bodyweight were allotted at random within litters to four treatments. The experiment was conducted for 33 days. The pigs were housed and group-fed in concrete-floored pens which were equipped with self-feeders and waterers. The experimental unit was of the open-shed type and the temperature fluctuated with the environmental temperature.

Composition of the experimental diets is shown in table 1 . The diets were formulated with 40,60 , or $80 \%$ yellow corn. The total niacin content of these rations supplied exclusively by corn was $8.11,12.17$ and 16.22 $\mathrm{mg}$. per $\mathrm{kg}$, respectively. One additional ration was fed which contained $80 \%$ yellow corn with $8.11 \mathrm{mg}$. of crystalline niacin added per $\mathrm{kg}$. of feed. Corn starch was used to keep the energy levels of all rations approximately the same. Gelatin and vitamin-free casein were used as supplements to maintain all rations at approximately $14 \%$ protein. The calculated tryptophan level was held constant $(0.11 \%)$ in all treatments.

All pigs were fed the $40 \%$ corn ration for 10 days. At the end of the initial period, 12 pigs were chosen at random within litters from the 16 pigs on trial and placed in metabolism cages for daily collections of feces and urine for 5 days after a 3-day adjustment period. Upon the completion of the initial metabolism trial the 12 pigs were randomly allotted to the $40 \%$ corn, $60 \%$ corn, $80 \%$ corn and $80 \%$ corn with added niacin. The pigs were fed these rations for 10 days 
and were then returned to the metabolism cages for a second metabolism trial lasting 5 days after a 3-day adjustment period.

Experiment 3. Ten Hampshire-Yorkshire crossbred barrows which averaged $32.6 \mathrm{~kg}$. of bodyweight were allotted to two treatments. The experiment was conducted for 41 days. Housing and management were the same as described in Experiment 2.

The experimental rations and their composition are shown in table 1. Rations fed were $80 \%$ milo with and without a supplement of $33.07 \mathrm{mg}$. of crystalline niacin per $\mathrm{kg}$. of feed. Vitamin-free casein and gelatin were used as supplements to maintain all rations at approximately $16.0 \%$ protein. The calculated tryptophan level was kept constant $(0.11 \%)$ in both treatments.

The pigs were fed their respective rations for 21 days and then 3 pigs from each ration treatment were chosen at random and placed in metabolism cages. Total collections were made for 3 days after a 3-day preliminary period. At the end of this metabolism trial, the two rations were reversed, i.e., the pigs previously fed the $80 \%$ milo ration were switched to the $80 \%$ milo ration plus niacin and the pigs fed the $80 \%$ milo ration plus niacin were switched to the $80 \%$ milo ration. Total collections were made again for 3 days after a 3-day adjustment period. Blood samples were obtained from each pig at the end of the trials and processed as described by Luce et al. (1966).

Metabolism cages, collection procedures and sample processing for all experiments were similar to those described previously (Luce et al., 1966). Nitrogen, $\mathbf{N}^{\prime}$-methylnicotinamide (NMN), $\mathrm{N}^{\prime}$-methyl-2-pyridone5-carboxamide (2 PY), niacin, diphosphopyridine nucleotide (DPN) and hematocrits were determined by procedures outlined previously by the above authors.

Student's $t$ test as outlined by Steel and Torrie (1960) was used to determine differences between treatment means. A probability level of $\mathbf{P}<.05$ or less was accepted as being significant. In Experiments 2 and 3, treatment differences for average daily feed intake and feed required per kilogram of gain could not be tested since the animals were groupfed and the treatments not replicated.

TABLE 1. COMPOSITION OF EXPERIMENTAL RATIONS

\begin{tabular}{|c|c|c|c|c|c|c|}
\hline \multirow[b]{2}{*}{ Ration designation } & \multicolumn{2}{|c|}{ Experiment 1} & & Experiment 2 & & \multirow{2}{*}{$\frac{\text { Experiment } 3}{A, B^{d}}$} \\
\hline & $\mathrm{A}, \mathrm{B}^{\mathrm{a}}$ & $\mathrm{C}, \mathrm{D}^{\mathrm{b}}$ & & $\mathrm{A} \quad \mathrm{B} \quad \mathrm{C}, \mathrm{D}^{\mathrm{e}}$ & & \\
\hline Treatment & Purified & Corn & $\begin{array}{l}40 \% \\
\text { Corn }\end{array}$ & $\begin{array}{l}60 \% \\
\text { Corn }\end{array}$ & $\begin{array}{l}80 \% \\
\text { Corn }\end{array}$ & $\begin{array}{l}80 \% \\
\text { Milo }\end{array}$ \\
\hline \multicolumn{7}{|l|}{ Ingredients, $\%$} \\
\hline Ground yellow corn & $\cdots$ & 79.8 & 40.0 & 60.0 & 80.0 & $\ldots$ \\
\hline Ground milo & $\ldots$ & $\ldots$ & $\ldots$ & $\ldots$ & $\ldots$ & 80.0 \\
\hline Corn starch & 71.2 & $\ldots$ & 35.7 & 17.9 & 0.2 & 1.4 \\
\hline Casein & 11.7 & 3.5 & 6.7 & 5.9 & 4.2 & 4.1 \\
\hline Gelatin & 6.1 & 6.1 & 4.9 & 3.7 & 3.3 & 3.3 \\
\hline Sucrose & 2.5 & 2.5 & 4.0 & 4.0 & 4.0 & 4.0 \\
\hline Lard & 2.5 & 2.5 & 4.0 & 4.0 & 4.0 & 3.0 \\
\hline Salt (iodized) & 0.5 & 0.5 & 0.5 & 0.5 & 0.5 & 0.5 \\
\hline Monosodium phosphate & 2.6 & 1.8 & 0.4 & 0.2 & $\ldots$ & $\ldots$ \\
\hline Dicalcium phosphate & & & 2.7 & 2.7 & 2.7 & 2.6 \\
\hline Ground limestone & 1.8 & 1.7 & $\ldots$ & $\ldots$ & $\ldots$ & $\ldots$ \\
\hline Trace minerals ${ }^{\mathrm{e}}$ & 0.1 & 0.1 & 0.1 & 0.1 & 0.1 & 0.1 \\
\hline Vitamin premix ${ }^{\mathrm{f}}$ & 1.0 & 1.0 & 1.0 & 1.0 & 1.0 & 1.0 \\
\hline L-lysine & $\cdots$ & 0.5 & $\cdots$ & $\ldots$ & $\ldots$ & $\cdots$ \\
\hline$\%$ Protein,Chemical analysis & 16.38 & 16.78 & 14.62 & 14.81 & 14.75 & 16.61 \\
\hline$\%$ Tryptophan, calculated & 0.14 & 0.14 & 0.11 & 0.11 & 0.11 & 0.11 \\
\hline \multicolumn{7}{|l|}{ Niacin, (mg./kg.) (total) } \\
\hline microbiological assay & 1.85 & 13.21 & 8.11 & 12.17 & 16.22 & 31.22 \\
\hline$\%$ Calcium, calculated & 0.68 & 0.66 & 0.71 & 0.71 & 0.71 & 0.70 \\
\hline$\%$ Phosphorus, calculated & 0.66 & 0.66 & 0.70 & 0.70 & 0.70 & 0.72 \\
\hline \multicolumn{7}{|c|}{$\begin{array}{l}\text { a Supplemented with } 11.35 \mathrm{mg} \text {. of niacin per } \mathrm{kg} \text { of feed for ration } \mathrm{B} . \\
\text { b Supplemented with } 23.81 \mathrm{mg} \text {. of niacin per } \mathrm{kg} \text { of feed for ration } \mathrm{C} \text {. } \\
\text { e Supplemented with } 8.11 \mathrm{mg} \text {. of niacin per } \mathrm{kg} \text { of feed for ration D. } \\
\text { a Supplemented with } 33.07 \mathrm{mg} \text {. of niacin per } \mathrm{kg} \text {. of feed for ration } \mathrm{B} \text {. } \\
\text { e Calcium Carbonate Company, Quincy, Ill. Standard swine mix. Content in } \%: \mathrm{Fe}, 10 ; \mathrm{Mn}, 10 ; \mathrm{Cu}, 1.0 ; \mathrm{Co}, 0.10 ; \mathrm{I} \text {, } \\
0.30 ; \mathrm{Zn}, 10 \text { and Ca, 9.1. }\end{array}$} \\
\hline
\end{tabular}


TABLE 2. EFFECT OF SOURCE OF NIACIN ON AVERAGE DAILY GAINS, DAILY FEED INTAKE AND FEED REQUIRED PER KG. OF GAIN (EXPERIMENT 1)

\begin{tabular}{|c|c|c|c|c|}
\hline Ration designation & A & B & $\mathrm{C}$ & $\mathrm{D}$ \\
\hline Treatment & Purified & Purified+niacin & Corn & Corn+niacin \\
\hline Niacin level, mg./kg. (total) & 1.85 & 13.21 & 13.51 & 37.32 \\
\hline $\begin{array}{l}\text { Pigs started per treatment } \\
\text { Pigs finished per treatment } \\
\text { Av. initial wt., kg. } \\
\text { Av. daily gain, kg. } \\
\text { Av. daily feed intake, kg. } \\
\text { Feed per kg. gain, kg. }\end{array}$ & $\begin{array}{l}6 \\
2^{\mathbf{b}} \\
22.7 \\
0.03 \\
0.54 \\
20.10\end{array}$ & $\begin{array}{l}6 \\
5^{\mathrm{b}} \\
21.2 \\
0.13 \\
0.69 \\
7.16\end{array}$ & $\begin{array}{l}6 \\
6 \\
20.3 \\
0.55^{c} \\
1.54^{\circ} \\
2.80\end{array}$ & $\begin{array}{l}6 \\
6 \\
20.3 \\
0.73^{\mathrm{e}} \\
1.92^{\mathrm{c}} \\
2.65\end{array}$ \\
\hline
\end{tabular}

a Duration of experiment was 70 days

$b$ Pigs either died or became paralyzed and were removed from treatment.

c Rations $C$ and $D$ differ significantly $(\mathrm{P}<01)$.

\section{Results}

Experiment 1. The results of the growth study are presented in table 2. Pigs fed the purified niacin-deficient ration performed very poorly and developed rather typical symptoms of a niacin deficiency within 2 or 3 weeks. The symptoms observed were diarrhea, rough hair coat, dermatitis, stiffness and paralysis of the hind quarters, irritability, anorexia and severe retardation in rate of gain. Two of the six pigs fed this ration died during the third week of the experiment and two more were destroyed when they became paralyzed and unable to rise. Two survived the experiment.

A slight response in pig performance was obtained by the addition of niacin to the purified ration. When measured by weight gain, the response was considered to be poor. Apparently the purified ration used in this study was not readily acceptable to the pigs as evidenced by their low daily feed intake which was apparent from the start. The pigs fed the purified ration plus niacin also showed symptoms of retarded rate of gain and anorexia, but the symptoms were less severe. One of the pigs fed this ration also became paralyzed and was removed from the experiment. No niacin deficiency symptoms were observed in the pigs fed the corn ration with the exception of a reduced rate of gain.

The average daily gain of $0.73 \mathrm{~kg}$. for the pigs fed the corn ration plus niacin was significantly greater $(\mathrm{P}<.01)$ than the 0.55 $\mathrm{kg}$. made by those fed the corn ration. The average daily feed intake was higher $(\mathrm{P}<.01)$ and feed required per $\mathrm{kg}$. of gain was less for the pigs fed the corn ration plus niacin than for those fed the corn ration.

Values for urinary excretion of NMN and 2 PY, nitrogen digestibility and nitrogen retention are shown in table 3. Average daily urinary excretion of NMN and 2 PY by the pigs was increased greatly when niacin was added to the corn ration. NMN and $2 \mathrm{PY}$ excretion were increased from 0.86 to 3.49 $\mathrm{mg} . /$ per day $(\mathrm{P}<.01)$ and from 0.51 to 4.46 $\mathrm{mg}$./per day respectively, by the addition of niacin to the $80 \%$ corn ration. Pigs fed the purified ration plus niacin also excreted greater amounts of NMN and $2 \mathrm{PY}$ than the pigs fed the purified ration.

Although all pigs were observed to be excreting NMN, the averages for 2 PY ex-

TABLE 3. EFFECT OF SOURCE OF NIACIN ON URINARY NMN AND 2 PY EXCRETION, NITROGEN DIGESTIBILITY AND NITROGEN RETENTION (EXPERIMENT 1)

\begin{tabular}{lcccc}
\hline \hline Ration designation & $\mathrm{A}$ & $\mathrm{B}$ & $\mathrm{C}$ & $\mathrm{D}$ \\
\hline Treatment & Purified & Purified +niacin & Corn & Corn+niacin \\
Niacin level, mg./kg. (total) & 1.85 & 13.21 & 13.51 & 37.32 \\
\hline Av. daily niacin intake, mg. & 0.17 & 4.31 & 20.73 & 58.44 \\
Av. daily NMN excretion, $\mathrm{mg}$. & 0.58 & 0.71 & $0.86^{\mathrm{a}}$ & $3.50^{\mathrm{a}}$ \\
Av. daily 2PY excretion, mg. & 0.76 & 1.04 & $0.51^{\mathrm{a}}$ & $4.46^{\mathrm{a}}$ \\
Av. daily nitrogen intake, gm, & 2.34 & 8.79 & 89.1 & 44.94 \\
Av. daily nitrogen digestion, $\%$ & 90.6 & 94.6 & 45.6 & 88.9 \\
Av. daily nitrogen retention, $\%$ & -96.4 & 14.7 & 35.0 \\
$\quad$ of intake & & & & \\
\hline
\end{tabular}

a Rations $\mathrm{C}$ and $\mathrm{D}$ differ significantly $(\mathrm{P}<.01)$. 
cretion include one pig fed the purified ration, one pig fed the purified ration plus niacin and two pigs fed the corn ration in which no $2 \mathrm{PY}$ could be detected in the urine.

Nitrogen digestibility was 90.6 and $94.6 \%$, respectively, for the pigs fed the purified ration and the purified ration plus niacin. Nitrogen digestibility for the pigs fed the corn ration and the corn ration plus niacin was 89.1 and $88.9 \%$, respectively, and did not differ significantly. The pigs fed the niacin-deficient, purified ration excreted more nitrogen than they consumed, whereas the pigs fed the purified ration plus niacin showed an average daily retention of $14.7 \%$ of nitrogen intake. The percent of nitrogen intake pigs fed the $40 \%$ corn ration than was required by those fed the other treatments.

The effect of rations and ration changes on urinary excretion of NMN for the experimental periods are shown in figure 1. NMN excretion increased in a linear manner for the pigs fed the 40,60 and $80 \%$ corn rations without supplemental niacin and the $80 \%$ corn ration with supplemental niacin, but the linear component was not statistically significant.

A linear increase was observed in NMN excreted daily when measured 13 days after the pigs were switched from the $40 \%$ corn ration (control) to the 60 and $80 \%$ corn rations and $80 \%$ corn ration with added

TABLE 4. EFFECT OF SOURCE OF NIACIN ON AVERAGE DAILY GAINS, FEED INTAKE, FEED CONVERSION, NIACIN DIGESTIBILITY AND NITROGEN DIGESTIBILITY AND RETENTION" (EXPERIMENT 2)

\begin{tabular}{|c|c|c|c|c|}
\hline Ration designation & A & $\mathrm{B}$ & $\mathrm{C}$ & $\mathrm{D}$ \\
\hline $\begin{array}{l}\text { Treatment } \\
\text { Niacin level, mg. } / \mathrm{kg} \text {. (total) }\end{array}$ & $\begin{array}{l}40 \% \\
\text { Corn } \\
8.10\end{array}$ & $\begin{array}{l}60 \% \\
\text { Corn } \\
12.16\end{array}$ & $\begin{array}{l}80 \% \\
\text { Corn } \\
16.21\end{array}$ & $\begin{array}{c}80 \% \\
\text { Corn + niacin } \\
24.32\end{array}$ \\
\hline $\begin{array}{l}\text { Pigs per treatment } \\
\text { Av. initial wt., kg. } \\
\text { Av. daily gain, kg. } \\
\text { Feed per kg. gain, kg. } \\
\text { Metabolism study }\end{array}$ & $\begin{array}{c}3 \\
42.4 \\
0.33 \\
3.67\end{array}$ & $\begin{array}{l}3 \\
43.4 \\
0.45 \\
2.54\end{array}$ & $\begin{array}{r}3 \\
42.2 \\
0.28 \\
2.97\end{array}$ & $\begin{array}{r}3 \\
43.3 \\
0.53 \\
2.54\end{array}$ \\
\hline $\begin{array}{l}\text { Av, daily niacin intake, mg. } \\
\text { Niacin digestibility, \% } \\
\text { Av. daily nitrogen intake, gm. } \\
\text { Av. daily nitrogen digestibility, \% } \\
\text { Av. daily nitrogen retention, \% } \\
\text { of intake }\end{array}$ & $\begin{array}{l}10.50 \\
75.9 \\
31.4 \\
91.5\end{array}$ & $\begin{array}{l}15.42 \\
71.5 \\
30.1 \\
89.0\end{array}$ & $\begin{array}{l}21.15 \\
77.3 \\
30.8 \\
91.2\end{array}$ & $\begin{array}{l}40.18 \\
70.3 \\
39.6 \\
86.5\end{array}$ \\
\hline
\end{tabular}

Duration of experiment was 33 days.

retained by the pigs fed the corn ration was greater than for those fed the corn ration plus niacin (45.6 versus $35.0 \%$ ).

Experiment 2. The results of the growth study and the niacin digestibility values observed are presented in table 4. Average daily gains for the pigs fed the 40,60 and $80 \%$ corn rations without supplemental niacin did not differ significantly. Average daily gains of the pigs fed the $80 \%$ corn ration with supplemental niacin were higher $(0.53 \mathrm{~kg}$. per day $)$ but were not significantly different from the gains of the pigs fed the $80 \%$ corn ration without supplemental niacin. Average daily feed intake was similar for the pigs fed the 40,60 and $80 \%$ corn rations without supplemental niacin. The pigs fed the $80 \%$ corn ration plus niacin consumed more feed than those fed the other rations. Considerably more feed was required per $\mathrm{kg}$. of gain for the niacin. Nevertheless, values observed were not significantly different.

Only a trace of 2 PY could be detected in the urine of three animals; one each on the $60 \%$ corn, $80 \%$ corn and $80 \%$ corn plus niacin rations.

A summary of nitrogen digestibility and retention data is also shown in table 4 . No significant differences were noted in nitrogen digestibility or percent of nitrogen intake retained.

Experiment 3. The results of the growth study are presented in table 5. Pigs fed the milo ration supplemented with $33.1 \mathrm{mg}$. of niacin per $\mathrm{kg}$. of feed gained $0.07 \mathrm{~kg}$. more per day than those fed the unsupplemented ration. The difference in gains was not statistically significant. The average daily feed intake was also higher for the pigs fed the milo ration plus niacin ( 2.58 vs. $2.36 \mathrm{~kg}$.). 


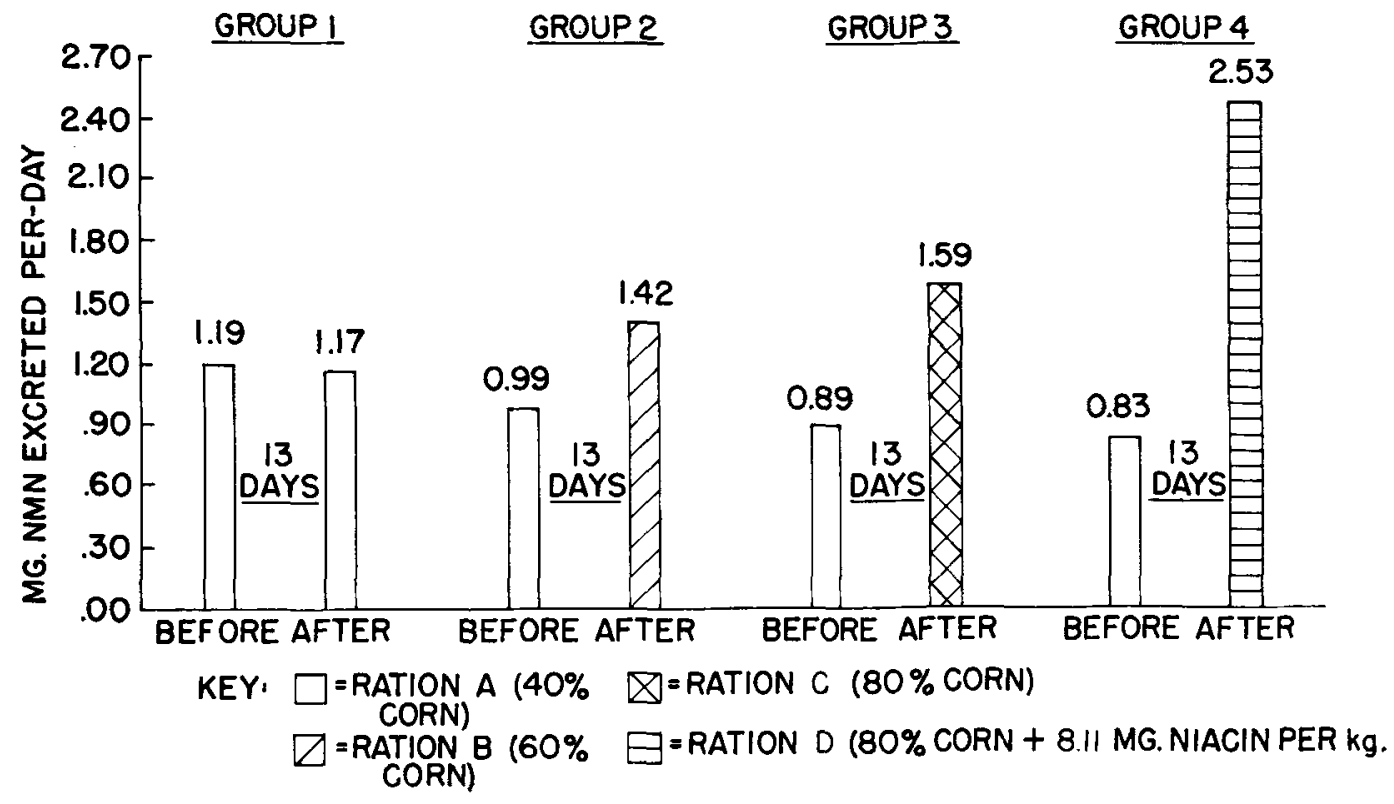

Figure 1. Effect of rations (before) and ration changes (after) on urinary excretion of NMN by swine (Exp. 2).

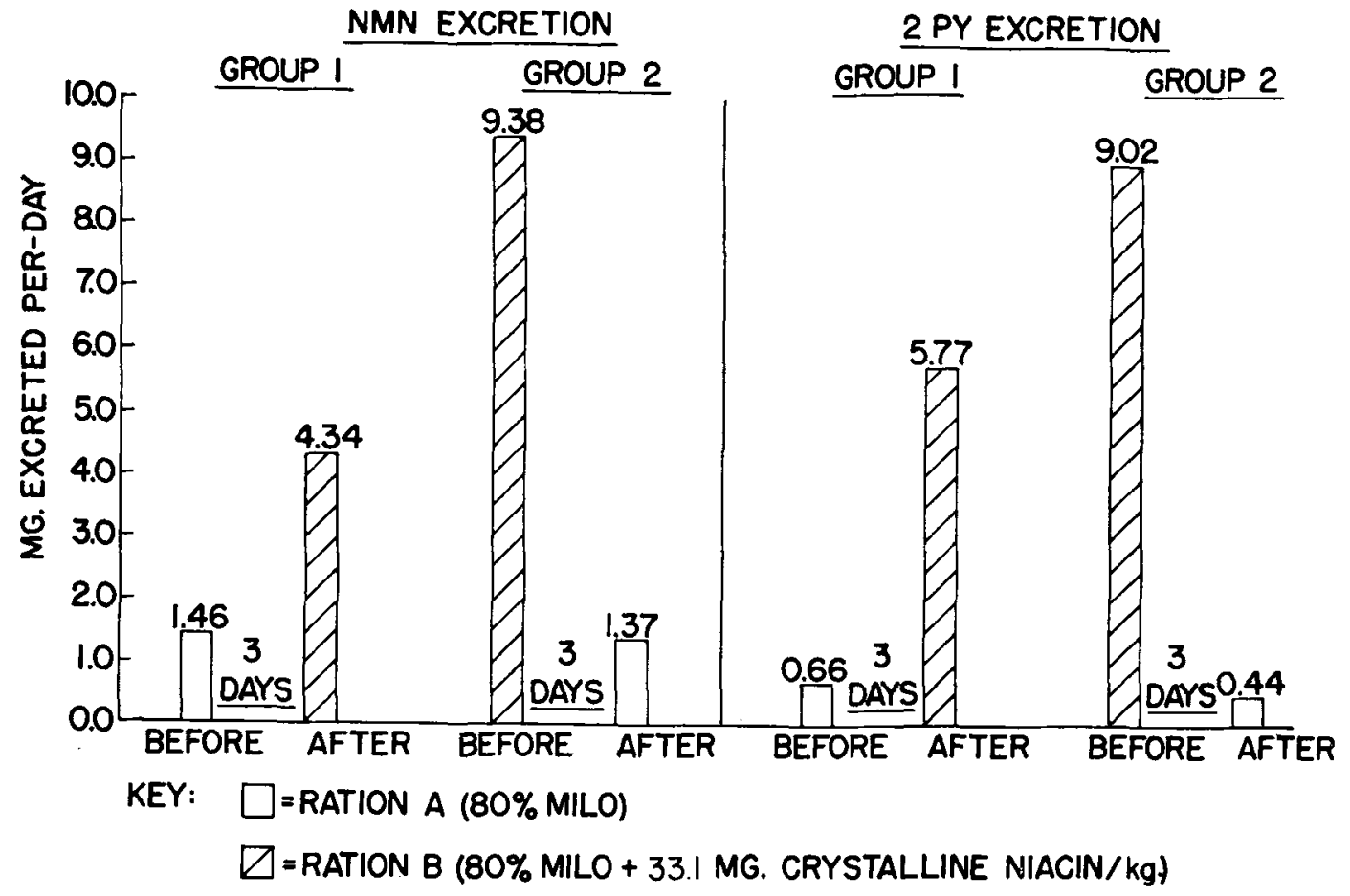

Figure 2. Effect of ration (before) and ration reversal (after) on urinary excretion of NMN and 2 PY by swine (Exp. 3). 
Feed per kg. of gain was the same for both treatments.

The effect of ration and ration reversal on urinary excretion of NMN and $2 \mathrm{PY}$ is shown in figure 2. The treatments had a marked influence on NMN and 2 PY excretion by the pigs. The average daily NMN excretion for the pigs fed the milo ration plus niacin was significantly greater $(\mathrm{P}<.01)$ than the excretion observed for the pigs fed
+5.11 and $-8.58 \mathrm{mg}$., respectively. After ration reversal, NMN excretion was significantly changed $(\mathrm{P}<.01)$.

The effect of ration and ration reversal on blood DPN levels is shown in figure 3. Blood DPN levels were higher for the pigs fed the milo ration plus niacin than for the pigs fed the milo ration (23.9 vs. $18.6 \mathrm{mcg}$. per $\mathrm{ml}$. of erythrocytes). Seven days after ration reversals, the pigs switched from the ration to

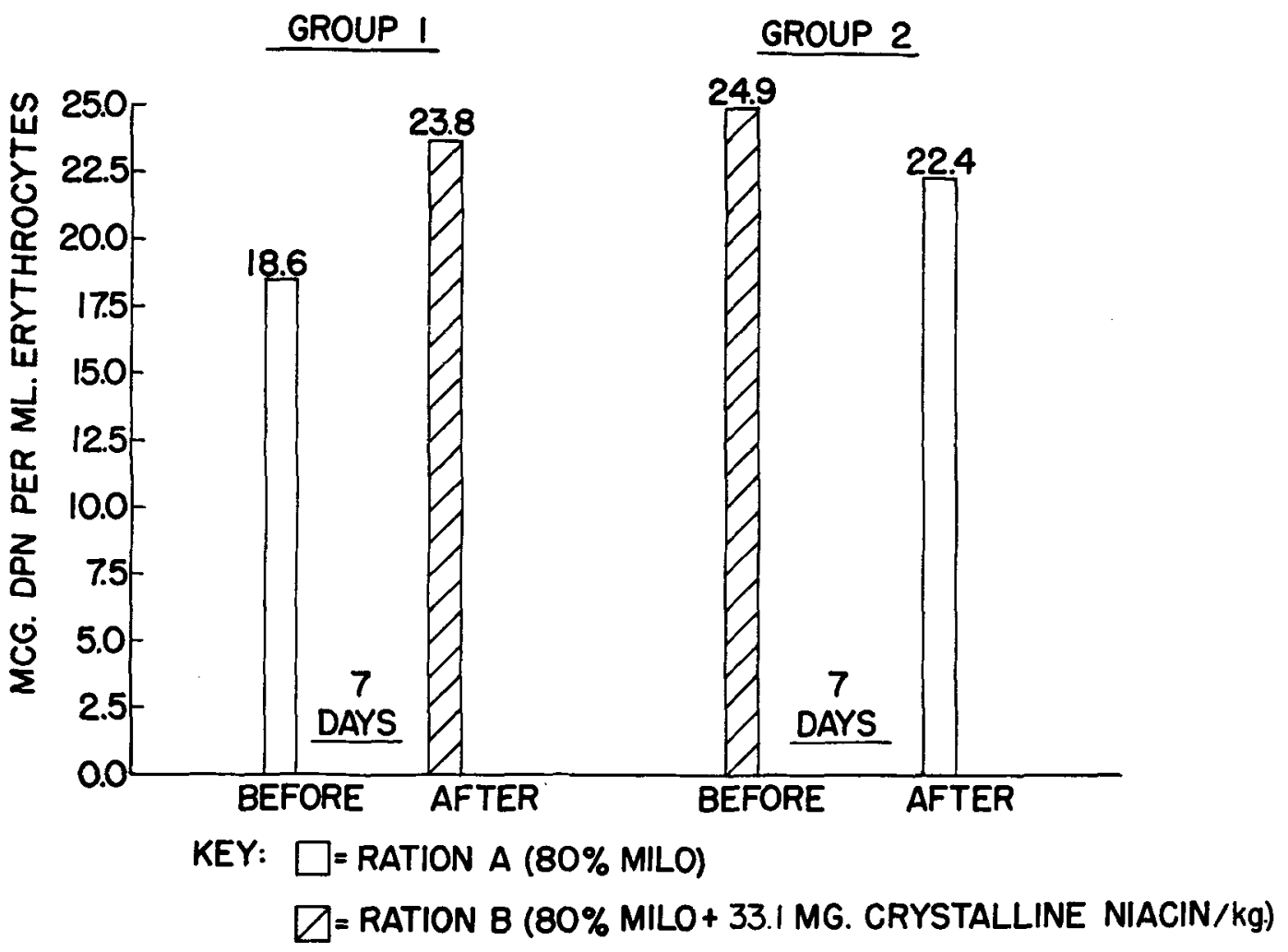

Figure 3. Effect of ration (before) and ration reversal (after) on blood DPN levels in swine (Exp. 3).

the milo ration. Similarly, the average daily 2 PY excretion of the pigs fed the milo ration plus niacin was greater than the excretion by the pigs fed the milo ration.

Three days after ration reversals, the pigs switched from the milo ration to the milo ration plus niacin showed an increase of 2.88 mg. per day in excretion of NMN. Pigs switched from the ration plus niacin to the milo ration showed a decrease of $8.01 \mathrm{mg}$. in average daily NMN excretion. Differences observed in 3 days in average daily 2 PY excretion for the same ration reversals were the ration plus niacin showed an increase of $5.3 \mathrm{mcg}$. in average DPN levels per $\mathrm{ml}$. of erythrocytes, whereas the pigs switched from the milo ration plus niacin to the milo ration showed a decrease of $2.5 \mathrm{mcg}$. However, the differences observed between rations before and after reversals were not statistically significant.

Nitrogen digestibility and retention data are also summarized in table 5. No significant differences were noted in nitrogen digestibility or percent of nitrogen intake retained for the pigs fed the two experimental rations. 
TABLE 5. EFFECT OF SOURCE OF NIACIN ON AVERAGE DAILY GAIN, FEED INTAKE AND FEED REQUIRED PER KG. OF GAIN, EXCRETION OF NIACIN AND NITROGEN DIGESTIBILITY AND RETENTION ${ }^{a}$ (EXPERIMENT 3)

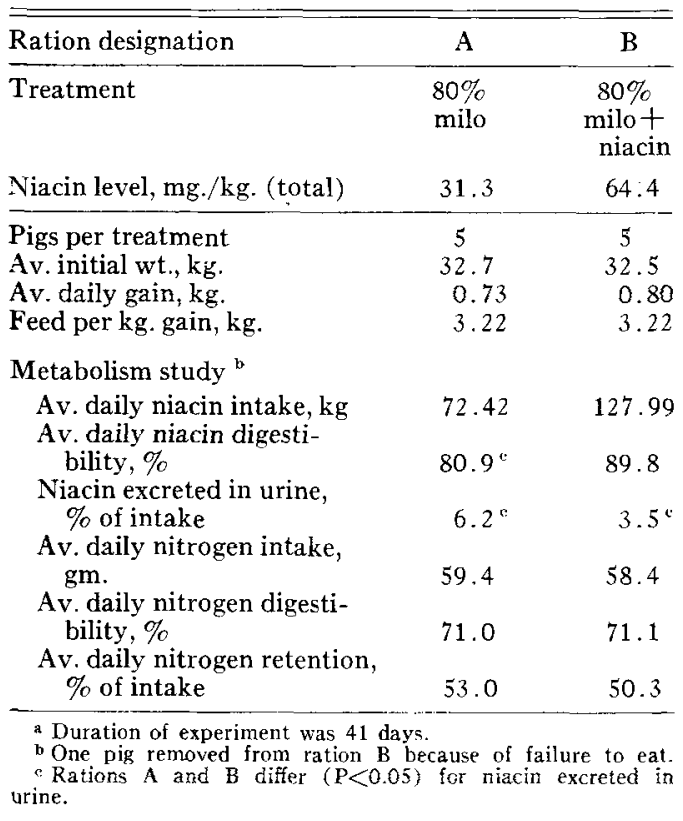

\section{Discussion}

The results of these studies indicate that the addition of crystalline niacin improved weight gains of growing pigs fed rations containing corn or milo as the primary source of energy. The increased gains observed in the pigs by the addition of niacin to the corn rations are in agreement with results reported by several workers (Braude et al., 1946; Luecke et al., 1947, Luecke et al., 1948 and Becker and co-workers, 1963). The total niacin content of the corn or milo ration used in these studies equalled or exceeded the level recommended by the National Research Council (1964) as the requirement for growing pigs. Therefore our results indicate that the niacin in yellow corn and milo is not appreciably available to swine.

Urinary NMN and 2 PY excretion were observed to be valid indices of the niacin intake of swine. Generally, NMN and 2 PY were observed to increase in a linear manner as levels of niacin were increased in the rations. The increased excretion of NMN or $2 \mathrm{PY}$ in the urine of pigs by the addition of niacin to the diet agrees with the findings of several workers (Luecke et al., 1947; Luecke et al., 1948; Perlzweig et al., 1950 and Self $e t a l ., 1960)$. Also, it was observed that great changes could be produced in NMN and 2 PY excretion within 3 days by the addition or removal of niacin from the diet of swine. This indicates the immediate effect which niacin intake has on these urinary metabolites.

NMN excretions appeared to be less variable than 2 PY excretion among pigs fed the same ration. In fact, 2 PY could not be detected constantly in the urine of pigs fed a low-niacin diet. This observation is in agreement with the work of Perlzweig et al. (1950) who were not able to detect $2 \mathrm{PY}$ in the urine of one pig on a stock ration (ingredients not given). The failure of $2 \mathrm{PY}$ to appear constantly in the urine was explained by Brown et al. (1958) who suggested that 2 PY was only excreted in significant amounts in humans when niacin or tryptophan is present in the diet in excess of metabolic needs.

Crystalline niacin when fed to pigs produced much greater excretions of NMN and 2 PY than the niacin originating from corn and milo. This observation was also shown by Luce $e t$ al. (1966) with wheat diets for swine. The data did suggest that the niacin (at least in corn) was not totally unavailable as increased corn levels in the diet of pigs caused slight increases in NMN excretion (if even only a low percent were available then one would expect a linear increase in NMN excretion with increased levels of corn).

Urinary excretion of free niacin by swine did not seem to adequately reflect differences in niacin intake. Only slight increases in free niacin excretion were observed by large increases of niacin in the diet of swine. This observation has also been shown by Luecke et al. (1947) and Wintrobe et al. (1945).

The niacin digestibility values $(70-89 \%)$ obtained in both the corn and milo trials are similar to the average value of $77 \%$ reported for humans by Denko et al. (1946). The high digestibility values indicate that the niacin of cereal grains is highly digestible, and is destroyed in the intestinal tract or experiences some other unknown fate. Thus niacin digestibility probably does not present a true picture of the availability of niacin ingested by the pig.

The increased blood DPN levels which were observed in pigs when niacin was added to the ration clearly demonstrate the effect of this vitamin on pyridine nucleotide synthesis. Similar relationships have been shown in rats and humans by several workers (Kohn and 
Klein, 1939; Hoagland and Ward, 1942; Handler and Kohn, 1943, Hoagland and others, 1943; Duncan and Sarett, 1951; Burch et al., 1955 and Morrison et al., 1963). The changes observed in 7 days in blood DPN levels by adding or removing niacin from the diet also demonstrated the rapid effect which this vitamin has on the DPN concentration of the blood. Duncan and Sarett (1951) reported that the administration of niacin to humans caused a rise in blood DPN levels within 4 hours.

Tryptophan has been shown by numerous workers to be a precursor of niacin in animals and microorganisms. It has been shown also to be a substitute for niacin in pigs by Luecke et al. (1948) and Powick et al. (1948). Nevertheless, tryptophan conversion to niacin in swine is apparently a very inefficient process ( 50 to 1 ) as shown by Firth and Johnson (1956).

Reber et al. (1951) demonstrated that a tryptophan deficiency produced a negative nitrogen balance in swine. An attempt was made in all experiments to keep the tryptophan level at or above $0.11 \%$ recommended by Hays (1961) as being the minimum requirement of swine of this weight range. Since no general reduction in nitrogen retention was observed in the pigs fed the lowniacin diets, in all probability no appreciable tryptophan conversion to niacin occurred.

\section{Summary}

Three experiments were conducted with 46 crossbred barrows to determine the availability of niacin in yellow corn and milo for growing pigs. Urinary excretion of free niacin, N'-methylnicotinamide (NMN), N'-methyl-2pyridone-5-carboxamide (2 PY), digestibility of niacin, blood levels of diphosphopyridine nucleotide (DPN), rate of gain, feed conversion and digestibility and retention of nitrogen were used as criteria for determining availability. In the first experiment, average daily gains and NMN excretion were increased significantly $(\mathrm{P}<.01)$, by the addition of $17.6 \mathrm{mg}$. of niacin per $\mathrm{kg}$. of feed to a corn ration. In the second experiment, average daily gains were similar for pigs fed 40,60 or $80 \%$ corn ration without added niacin. Gains were increased by the addition of $8.1 \mathrm{mg}$. of crystalline niacin per $\mathrm{kg}$. of feed to the $80 \%$ corn ration. NMN excretion increased in a linear manner for pigs fed the 40,60 and $80 \%$ corn rations and the $80 \%$ corn ration with added niacin. In the third experiment, average daily gains, NMN and 2 PY excretions and blood DPN levels were increased by the addition of $33.0 \mathrm{mg}$. of niacin per $\mathrm{kg}$. to an $80 \%$ milo ration. Differences observed in NMN excretion were significant $(\mathrm{P}<.025)$. Generally only slight differences were noted in free niacin excretion, nitrogen retention and digestibility and feed conversion. The results indicate that the niacin of corn and milo is largely unavailable to swine.

\section{Literature Cited}

Becker, D. E., J. R. Mitchell, Jr., A. H. Jensen, S. W. Terrill and H. W. Norton. 1963. Nicotinic acidtryptophan relationship in the nutrition of the weanling pig. J. Animal Sci. 22:1117. (Abstr.).

Braude, R., S. K. Kon and E. G. White. 1946. Observations on the nicotinic acid requirement of pigs. Biochem. J, 40:843.

Brown, R. R., V. M. Vivian, M. S. Reynolds and J. M. Price. 1958. Some aspects of tryptophan metabolism in human subjects. II. Urinary tryptophan metabolites on a low niacin diet. J. Nutr. 66:599.

Burch, H. B., C. A. Storvick, R. L. Bicknell, H. C. Kung, L. G. Alejo, W. A. Everhart, O. H. Lowry, C. G. King and O. A. Bessey. 1955. Metabolic studies of precursors of pyridine nucleotides. J. Biol. Chem. 212:897.

Denko, C. W, W. E. Grundy, J. W. Porter and G. H. Berryman. 1946. The excretion of B-complex vitamins in the urine and feces of seven normal adults. Arch. Biochem. 10:33.

Duncan, M. and H. P. Sarett. 1951. Effect of nictonic acid and tryptophan on pyridine nucleotides of red blood cells in man. J. Biol. Chem. 193:317.

Firth, J. and B. C. Johnson. 1956. Quantitative relationship of tryptophan and nicotinic acid in the baby pig. J. Nutr. 59:223.

Handler, P. and H. I. Kohn. 1943. The mechanism of cozymase synthesis in the human erythrocyte: A comparison of the roles of nicotinic acids and nicotinamide. J. Biol. Chem. 150:447.

Harper, A. E., B. D. Punekar and C. A. Elvehjem. 1958. Effect of alkali treatment on the availability of niacin and amino acids in maize. J. Nutr. 66:163.

Hays, V. W. 1961. Proteins and amino acids in swine nutrition. A Century of Nutrition Progress. Midwest Feed Manufacturers Assoc., Kansas City, Mo.

Hoagland, C. L. and S. M. Ward. 1942. The quantitative determination of factor $\mathrm{V}$ by measurement of nitrite produced by Hemophilus influenzae. J. Biol. Chem. 146:115.

Hoagland, C. L., S. M. Ward and R. E. Shank. 1943. Synthesis of coenzyme and Factor V in erythrocytes and the excretion of nicotinic acid derivatives in the urine following the ingestion of nicotinic acid and nicotinamide. J. Biol. Chem. 151:369.

Kodicek, E., R. Braude, S. K. Kon and K. G. Mitchell. 1956. The effect of alkaline hydrolysis of maize on the availability of its nicotinic acid to the pig. Brit. J. Nutr, 10:51.

Kodicek, E., R. Braude, S. K. Kon and K. G. 
Mitchell. 1959. The availability of nicotinic acid in tortilla baked from maize treated with limewater. Brit. J. Nutr. 13:363.

Kodicek, E. and P. W. Wilson. 1959. The availability of bound nicotinic acid to the rat. 1. The effect of lime-water treatment of maize and subsequent baking into tortilla. Brit. J. Nutr. 13:418.

Kodicek, E. 1960 . The availability of bound nicotinic acid to the rat. 2. The effect of treating maize and other materials with sodium hydroxide. Brit. J. Nutr. 14:13.

Kohn, H. I. and J. R. Klein. 1939. The synthesis of cozymase and of factor $\mathrm{V}$ from nicotinic acid by the human erythrocyte in vitro and in vivo. $\mathrm{J}$ Biol. Chem. 130:1.

Laguna, J. and K. J. Carpenter. 1951. Raw versus processed corn in niacin-deficient diets. J. Nutr, $45: 21$,

Luce, W. G., E. R. Peo, Jr. and D. B. Hudman. 1966. The availability of niacin in wheat for swine. J. Nutr. 88:39.

Luecke, R. W., W. N. McMillen, F. Thorpe, Jr. and C. Tull. 1947. The relationship of nicotinic acid, tryptophan and protein in the nutrition of the pig. J. Nutr. $33: 251$.

Luecke, R. W., W. N. McMillen, F. Thorpe, Jr. and C. Tull. 1948. Further studies on the relationship of nicotinic acid, tryptophan and protein in the nutrition of the pig. J. Nutr. 36:417.

Morrison, M. A., M. S. Reynolds and A. E. Harper. 1963. Effect of increments of tryptophan and niacin on growth and the concentration of blood and liver pyridine nucleotides. J. Nutr. 80:441.
N.R.C. 1964. Nutrient requirements of domestic animals. No. II. Nutrient requirements of swine. National Research Council Publ. 648.

Pearson, W. N., S. J. Stempfel, J. S. Valenzuela, M. H. Utley and W. J. Darby. 1957. The influence of cooked vs. raw maize on the growth of rats receiving a $9 \%$ casein ration. J. Nutr. 62:445.

Perlzweig, W. A., F. Rosen and P. B. Pearson. 1950. Comparative studies in niacin metabolism. The fate of niacin in man, rat, dog, pig, rabbit, guinea pig, goat, sheep and calf. J. Nutr. 40:453.

Powick, W. C., N. R. Ellis and C. N. Dale. 1948. Relationship of tryptophan to nicotinic acid in the feeding of growing pigs. J. Animal Sci, 7:228.

Reber, E., C. K. Whitehair and R. MacVicar. 1951. Utilization of DL-tryptophan in the baby pig. J. Animal Sci. 10:1060. (Abstr.).

Self, H. L., R. R. Brown and J. M. Price. 1960. Quantitative studies on the metabolites of tryptophan in the urine of swine. J. Nutr. 70:21.

Squibb, R. L., J. E. Braham, G. Arroyave and N. S. Scrimshaw. 1959. A comparison of the effect of raw corn and tortillas (lime treated corn) with niacin, tryptophan or beans on growth and muscle niacin of rats. J. Nutr. $67: 351$.

Steel, R. G. D. and J. H. Torrie. 1960. Principles and Procedures of Statistics. McGraw-Hill Book Co., Inc., New York.

Wintrobe, M. M., H. J. Stein, R. H. Follis, Jr. and S. Humphries. 1945. Nicotinic acid and the level of protein intake in the nutrition of the pig. $J$. Nutr. 30:395. 